\title{
陽電子でみるアルミニウム合金中の原子空孔の挙動
}

\section{白井 泰治*}

\author{
Journal of Japan Institute of Light Metals, Vol. 56, No. 11 (2006), pp. 629-634
}

\section{Behavior of vacancies in aluminum watched by positrons}

\author{
Yasuharu SHIRAI*
}

Keywords: vacancy, aluminum, age hardening, diffusion, vacancy-solute interaction

\section{1.はじめに}

アルミニウム合金の時効硬化は，原子空孔が過飽和の溶質 原子を運び，溶質クラスタである GPゾーンや準安定・安定 析出物を形成する現象である。溶質原子（置換型）の拡散速 度は，合金中に存在する原子空孔の量に比例する。したがっ て, とりわけ低温時効は, 溶体化処理後の急冷処理によって 材料中に凍結された原子空孔に支配されている。時効現象の kinetics を理解するためには，原子空孔の濃度や移動温度，な かでも凍結原子空孔の挙動を知ることが肝要である。

一方, 陽電子は, 材料中のナノメートルスケールの構造欠 陥を極めて感度よく検知する。ナノ構造欠陥とは, 別の言葉 で言えば結晶格子欠陥であり, 具体的には原子空孔 ${ }^{1)} \cdot$ 空孔 集合体・ボイド，転位 ${ }^{2)}$ 等である。特に，原子空孔の評価技 術として陽電子消滅は独自の高い能力を有しており, ほかに 適切な測定手段は存在しない。

本稿では, 陽電子消滅法による空孔計測の原理を簡単に解 説した後, 著者らの測定結果を中心に, アルミニウム合金中 の原子空孔の挙動について，できるだけ平易に紹介する。ア ルミニウム中の置換型溶質原子の移動・拡散は, 原子空孔機 構で起こっていることに疑いの余地はない。以下では，原子 空孔の挙動を中心に説明しているが，合金の場合には常に同 時に溶質原子が拡散し GP ゾーンのような溶質クラスタを形 成していることを念頭に，読み進めていただきたい。

\section{2. 陽電子消滅法の原理}

陽電子 $\left(\mathrm{e}^{+}\right)$とは, 電子 $\left(\mathrm{e}^{-}\right)$の反粒子であり, 質量 $(m)$ は電子と同じであるが正の電荷を持っている。陽電子は，市 販の陽電子線源 ( $\beta^{+}$崩壊核種) を購入すれば簡単に利用す ることができる。線源から放出される陽電子を直接試料に入 射させる方法が最む簡便である。図 1 は最むよく用いられる 陽電子線源 ${ }^{22} \mathrm{Na}$ を例に, 基本的な陽電子消滅実験の原理を 示したあのである ${ }^{1)} 。{ }^{22} \mathrm{Na}$ は, 陽電子を放出するのとほぼ同 時に $1.28 \mathrm{MeV}$ のエネルギーをむった $\gamma$ 線を放出する。材料に

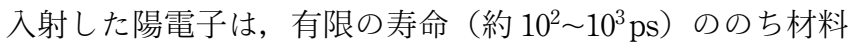
中の電子と対消滅し, エネルギー $0.511 \mathrm{MeV}\left(=m c^{2}\right.$, 電子.
陽電子の質量 $m$ に対応, $c$ は光速）の消滅 $\gamma$ 線 2 本をほぼ正 反対（ $\pi$ ラジアン）方向に放出する。陽電子の誕生を告げる $1.28 \mathrm{MeV}$ のエネル゙ーをむつ $\gamma$ 線を検出してから, 陽電子の 消滅を告げる $0.511 \mathrm{MeV}$ のエネルギーをもつ $\gamma$ 線を検出する までの時間差を計測すれば, 陽電子寿命が得られる（ $\gamma-\gamma$ 同 時計測法)。陽電子寿命は, 消滅位置における電子密度で決 定され，それに反比例する。

一方, 陽電子. 電子対の運動量 $p$ は陽電子・電子対の消滅 後屯保存される。したがって, $p$ の $\gamma$ 線に垂直な成分 $p_{\perp}$ に よって, 2 本の消滅 $\gamma$ 線は $\pi$ から $\Delta \theta$ のずれ $\left(\Delta \theta=p_{\perp} / m c\right)$ をむって放出される (図 1)。消滅前の陽電子の運動量は結晶 中の電子のそれに比べて無視できる程度なので, このずれを 測定すれば消滅前に電子が持っていた運動量がわかる。すな わち各 $\theta$ における消滅 $\gamma$ 線の数 $N(\theta)$ (角相関曲線) を測定 することによって材料中の電子の運動量分布を知ることがで きる。

陽電子 . 電子対の運動量の $\gamma$ 線方向の成分 $p_{/ /}$は, 消滅 $\gamma$ 線のエネルギー $E(=0.511 \mathrm{MeV})$ にドップラー・シフト $\left(\Delta E=p_{/ /} / 2\right)$ を与える（図 1)。したがって，消滅 $\gamma$ 線のエネ ルギー分布 $N(E)$ を精密に測定することによっても, 材料

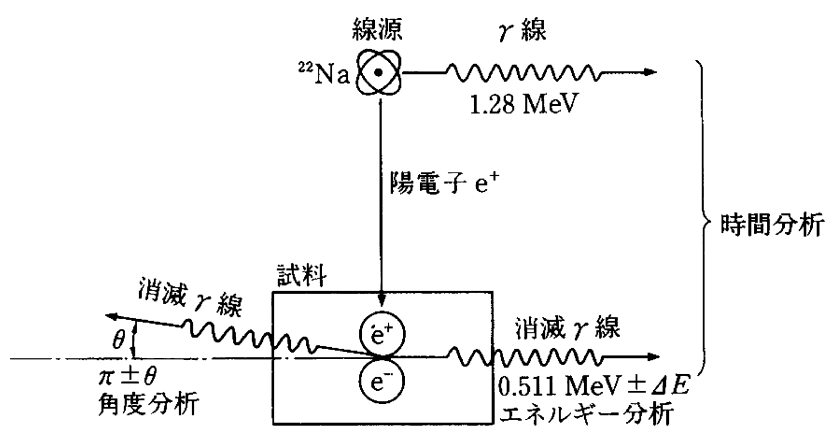

図 1 陽電子消滅法の原理を示す模式図 ${ }^{1)}$ 。陽電子線源 から放出され試料内に打ち込まれた陽電子は，試料内 の電子と対消滅し 2 本の消滅 $\gamma$ 線となって正反対方向 に放出される。陽電子が試料に入射してから消滅する までの時間を計測するのが陽電子寿命測定法であり, 原子空孔があると陽電子寿命が長くなる。

\footnotetext{
* 大阪大学大学院工学研究科（干 565-0871 大阪府吹田市山田丘 2-1）。Graduate School of Engineering, Osaka University（2-1 Yamada-oka, Suita-shi, Osaka 565-0871).E-mail: shirai@mat.eng.osaka-u.ac.jp
} 受付日：平成 18 年 10 月 4 日 受理日：平成 18 年 10 月 16 日 

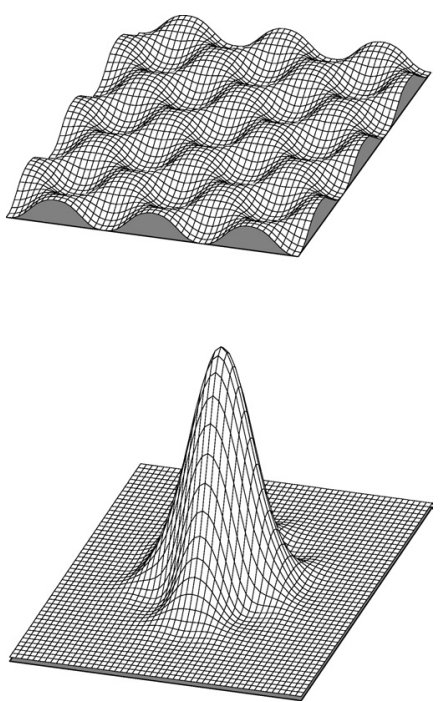

図 2 アルミニウム中の陽電子の状態 $(\text { 計算 })^{3)}$ 。上は完 全結晶の（100）面上の陽電子の密度分布。陽電子は イオン殼を避け，格子間位置に広がる。下は中央のイ オン殼を抜取り原子空孔を導入した場合。陽電子は原 子空孔に捕獲され，その位置に局在する。その結果， 陽電子寿命はおよそ $70 \mathrm{ps}$ 長くなる。

中の電子の運動量分布を知ることが可能である。最近，左右 に放出される 2 本の消滅 $\gamma$ 線を同時に計測し, バックグラウ ンドを下げて, 高運動量部の情報を精度よく抽出することに よって, 空孔周辺や析出物の元素分析を行うことが可能と なってきた（陽電子消滅 $\gamma$ 線同時計測ドップラー幅広がり 法)。これについては，いずれ稿を改めて紹介したい。

\section{3. 空孔型欠陥を探る陽電子}

欠陥の極めて少ない金属材料では，陽電子はその正電荷の ゆえにイオン殸から離れた位置, すなわち格子間位置で存在 確率が最も高い。図 2 上にアルミニウム結晶格子中の（100） 面上の陽電子密度 (計算) ${ }^{3}$ )を示す。縦軸は陽電子密度（任 意単位）である。図中の陽電子密度の低いところは，アルミ ニウム原子のイオン殸が存在する部分である。陽電子はクー ロン反発力によりイオン殼を避け, 主に格子間位置に広がっ ている。陽電子は主として結晶格子間にある伝導電子と対消 滅し，この場合に観測される陽電子寿命（よく焼なまされた アルミニウム中の陽電子寿命） $\tau_{\mathrm{f}}$ はおよう $160 \mathrm{ps}\left(1.6 \times 10^{-10}\right.$ 秒）である ${ }^{3)}$ 。

一方，材料中に空孔やその集合体，転位などイオン殻密度 が低い部分が存在すると, その部分は周囲に対し負に帯電し ており, 正の電荷を持つ陽電子はクーロン引力によってそこ に捕獲され, その位置で電子と対消滅する。図 2 下にアルミ ニウム中の原子空孔に捕獲された陽電子の状態 (計算) ${ }^{3)}$ を 示す。図 2 上と同様，アルミニウム結晶格子中の（100）面 上の陽電子密度を示しているが，この場合は中央に原子空孔 が存在する。陽電子はこの原子空孔に捕獲され，1個の陽電 子が全部そっくり単一の原子空孔の中に納まっている。原子 空孔内には内殼電子が存在せず，また伝導電子も密度が低い ため, 陽電子寿命は長くなる。アルミニウムの単原子空孔中 の陽電子寿命は，拈よそ $230 \mathrm{ps}$ であり，完全結晶中より約 70 ps 長い ${ }^{3)}$ 。

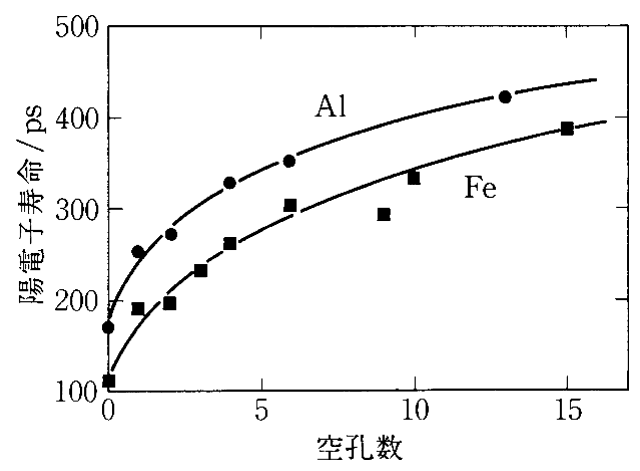

図 3 アルミニウムおよび鉄中の空孔・空孔集合体（マ イクロボイド) 中の陽電子寿命 (計算值 $)^{4)}$ 。横軸は, マイクロボイドの大きさを，その中に含まれる原子空 孔の数で表している。ボイドが成長すると陽電子寿命 は $500 \mathrm{ps}$ に漸近する。

空孔が集まってマイクロボイドとなると, 内部の電子密度 が減少するため陽電子寿命は更に長くなり, ボイドの成長に

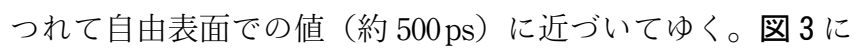
アルミニウムおよび鉄の中の微小空孔集合体での陽電子寿命 の値 (計算) $)^{4)}$ を示す。横軸は, マイクロボイドの大きさを その中に含まれる原子空孔の数で示してあり, 縦軸は各サイ ズのマイクロボイドで消滅する陽電子の寿命である。

一般に金属中での陽電子消滅寿命スペクトル $T(t)$ は, 次 のような形で表される。

$$
T(t)=\left(I_{0} / \tau_{0}\right) \cdot \exp \left(-t / \tau_{0}\right)+\sum\left(I_{i} / \tau_{i}\right) \cdot \exp \left(-t / \tau_{i}\right)
$$

ここで, $\tau_{i}(i=1,2, \ldots n)$ は各欠陥種における陽電子寿命, $I_{i}$ はそれぞれの寿命成分の相対強度である。第 1 成分 $\tau_{0}$ は, マ トリックス成分であり, 格子欠陥が少ない場合（ $I_{0}$ がほぼ 1 のとき), 完全結晶中での陽電子寿命 $\tau_{\mathrm{f}}$ となる。この值は, アルミニゥムの場合，上に述べたように約 $160 \mathrm{ps}$ である。 欠陷が陽電子を捕獲すると, 見かけ上この值は $\tau_{\mathrm{f}}$ より短くな る ${ }^{1)}$ 。実測スペクトルの計算機を用いた成分解析によって各 $\tau_{i}, I_{i}$ を求め, $\tau_{i}$ の值から欠陥種 (図 3 参照) を, $I_{i}$ の值から その量を推定することができる ${ }^{11}$ 。金属中の原子空孔やその 集合体に陽電子が捕獲される速度は大变速く, そのため $1 \mathrm{ppm}$ の原子空孔の存在でも検出することが可能である。

陽電子寿命の絶対值は, それ自身が物理量で, 実験值と第 1 原理計算から理論的に予測される值とを直接比較すること が可能である ${ }^{5,6)}$ 。そのため, 実験で得られた陽電子寿命ス ペクトルの成分解析（上式の各 $\tau_{i}, I_{i}$ を求める）から, 材料 中に存在する各欠陥の種類と量を独立に知ることができ る ${ }^{5), 6)}$ 。

本稿では, 陽電子寿命法によるアルミニウム合金中の原子 空孔計測に話題を限定する。また細かい議論を避けるために, 主に平均陽電子寿命変化のみを示す。結晶中に陽電子を捕獲 する欠陥として原子空孔のみが存在する場合, 平均陽電子寿 命 $\tau_{\mathrm{M}}$ は次式のように表される。

$$
\tau_{\mathrm{M}}=I_{0} \cdot \tau_{0}+I_{\mathrm{V}} \cdot \tau_{\mathrm{V}}, \quad\left(I_{0}+I_{\mathrm{V}}=1\right)
$$

ここで， $\tau_{\mathrm{V}}$ は原子空孔における陽電子寿命， $I_{\mathrm{V}}$ は原子空孔に 捕獲されて電子と対消滅した陽電子成分の相対強度である。 


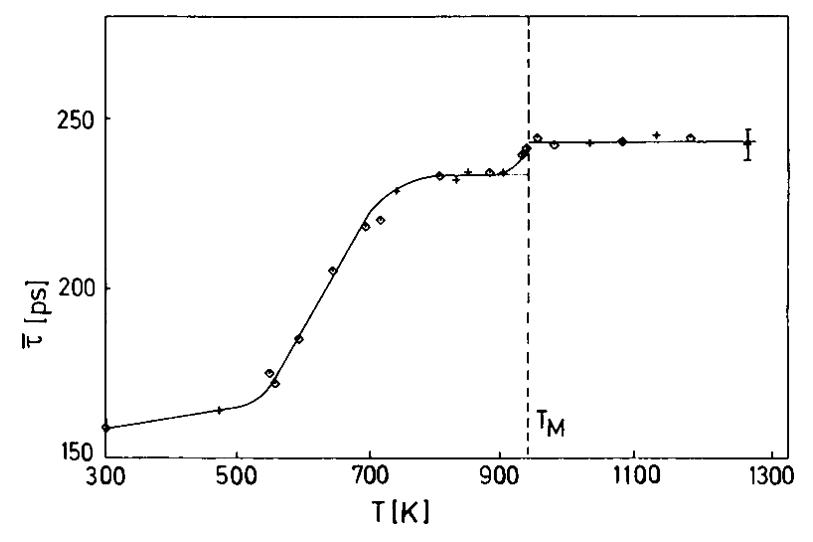

図 4 アルミニウム中の陽電子寿命のその場測定結果 ${ }^{7)}$ 。 $500 \mathrm{~K}$ 過ぎから融点にかけての寿命值の大幅な上昇は, 熱平衡原子空孔による。

原子空孔濃度が十分低い場合，ほとんどの陽電子は格子間位 置で消滅し $\left(I_{0} \simeq 1\right)$, 平均陽電子寿命は約 $160 \mathrm{ps}$ となる。空 孔濃度が原子比でおよそ $1 \mathrm{ppm}$ 以上に上昇すると, 空孔に捕 獲されて長い陽電子寿命 $\left(\tau_{\mathrm{V}}\right)$ で消滅する陽電子の割合が増 加するために, 平均陽電子寿命 $\tau_{\mathrm{M}}$ は上昇してゆく。空孔濃 度が $100 \mathrm{ppm}$ に近づくと $\tau_{\mathrm{M}}$ は $\tau_{\mathrm{V}}$ に漸近してゆく。空孔濃度 が $100 \mathrm{ppm}$ 以上になるとほとんどすべての陽電子が空孔に捕 獲されて $\left(I_{\mathrm{V}} \simeq 1\right)$, 平均陽電子寿命 $\tau_{\mathrm{M}}$ は $\tau_{\mathrm{V}}$ （およそ $230 \mathrm{ps}$ ） に等しくなる（飽和する）。

\section{4. アルミニウム中の熱平衡原子空孔}

アルミニウム合金の時効中の空孔挙動を知るためには，ま ずアルミニウムの熱平衡原子空孔について知る必要がある。 図 4 は, 純アルミニウム中の平均陽電子寿命の温度变化を示 している ${ }^{7)}$ 。その場測定の結果であり, 横軸は試料温度であ る。加熱時と冷却時の值が一致しているので, この変化は熱 平衡状態での值である。室温では, アルミニウム完全結晶格 子中の陽電子寿命約 $160 \mathrm{ps}$ を示している。室温から $500 \mathrm{~K}$ 付 近までの直線的で緩やかな寿命上昇は，結晶格子の熱膨張に よって少しずっ電子密度が低下するためである。この変化か ら，通常の時効温度（摂氏 250 度以下）におけるアルミニゥ ム中の熱平衡原子空孔濃度は, 陽電子消滅の検出限界以下で あることが明らかである。

$500 \mathrm{~K}$ を超えると陽電子寿命は格子の熱膨張による上昇を はるかに超えて, 大きな上昇を見せる。この上昇が熱平衡原 子空孔によるものである。熱平衡原子空孔濃度 $C_{\mathrm{v}}$ は, 以下 の式に従って, 温度上昇に伴って指数関数的に増大すること はよく知られている。

$$
C_{\mathrm{v}}=A \cdot \exp \left(-H_{\mathrm{F}} / k T\right)
$$

ここで, $A$ は定数 (2〜5), $H_{\mathrm{F}}$ は原子空孔形成エネルギー, $k$ はボルッマン定数， $T$ は絶対温度である。アルミニウムの場 合, $500 \mathrm{~K}$ 付近で $C_{\mathrm{v}}$ は $10^{-6}$ のオーダに到達し, 陽電子寿命に 影響を与える濃度となる。すなわち, 一部の陽電子が熱平衡 原子空孔に捕獲され， $230 \mathrm{ps}$ の長い寿命で消滅する。その結 果, (2) 式に従って平均陽電子寿命（縦軸）は急上昇を始め る (図 4 参照)。

$700 \mathrm{~K}$ を越えた付近で, 平均陽電子寿命の上昇は鈍くなり, $230 \mathrm{ps}$ に漸近してゆく。これは, 空孔濃度の上昇が鈍るため

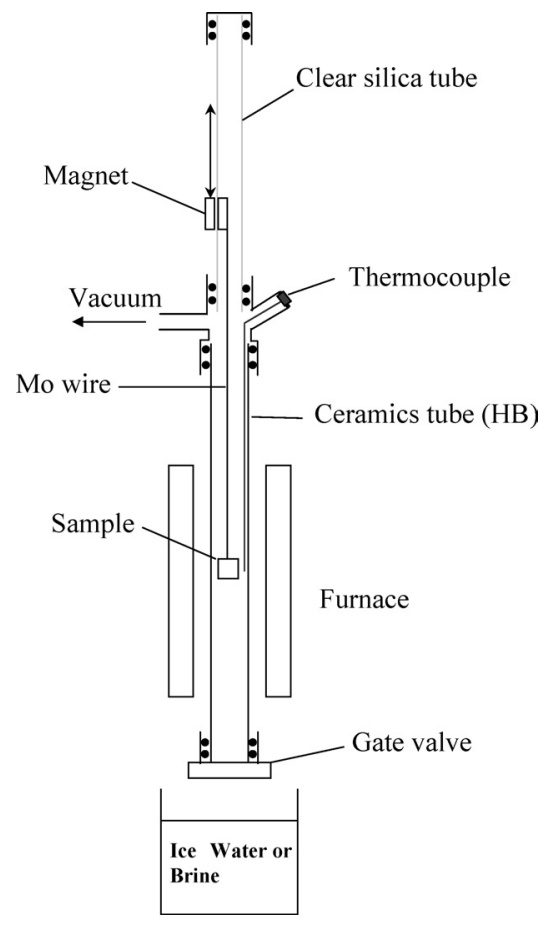

図 5 高温での熱平衡空孔を速い急冷速度で材料中に凍 結させるために作成した急冷炉 ${ }^{8)}$ 。試料は自由落下に より，再現性よく冷浴中に急冷される。

ではない。空孔濃度は（3）式に従って増え続けるが, すべ ての陽電子が空孔に捕獲されて $230 \mathrm{ps}$ で消滅するようになり, 平均寿命が $230 \mathrm{ps}$ に飽和してしまうためである。これは（2） 式から自明であろう。このような飽和現象は, 空孔濃度が原 子比で通常 $10^{-4}$ のオーダに到達すると観測される。図 4 の変 化から, 原子空孔形成エネルギー $H_{\mathrm{F}}$ として, $0.69 \mathrm{eV}$ が求め られている。この値を用いれば, 各温度での熱平衡空孔濃度 は（3）式から計算できる。融点での平均陽電子寿命の更な る上昇は, 融解に伴う变化である。すなわち, 液体アルミニ ウム中の陽電子寿命は, 単一原子空孔中のそれよりも $10 \mathrm{ps}$ 程度長いことがわかる。

\section{5. 急冷アルミニゥム中の凍結空孔}

アルミニゥム合金の初期時効は, 溶体化処理後の急冷に よって試料中に閉じ込められた熱平衡空孔, すなわち凍結空 孔の働きによる。これは, 時効温度における熱平衡空孔濃度 は溶体化温度における熱平衡空孔濃度に比較すると桁違いに 低いこと, ならびに, 溶質原子の拡散速度は原子空孔濃度に 比例することを考え合わせれば, 自明である。陽電子消滅寿 命法を用いると, 凍結空孔濃度や, 凍結された空孔が移動を 始める温度を直接見ることができる。

図 5 は, アルミニウム合金中の凍結空孔を研究するために 作成した縦型炉 ${ }^{8)}$ である。マグネットで固定された鉄片から モリブデン細線でつるされた試料は, 炉の均熱部にセットさ れる。溶体化焼なまし後, 内部を大気圧のアルゴンガスで満 たし，底のゲートバルブを開き，直ちにマグネットをはずす。 試料は自由落下し, 直下の急冷浴に焼き入れられる。焼入れ 浴は, 純アルミニウムの場合は $-20^{\circ} \mathrm{C}$ に冷却した飽和食塩水 を，合金の場合は水水を用いた。この炉を用いれば，再現性 よく高速焼入れ状態を得ることができる。溶質原子の種類や 


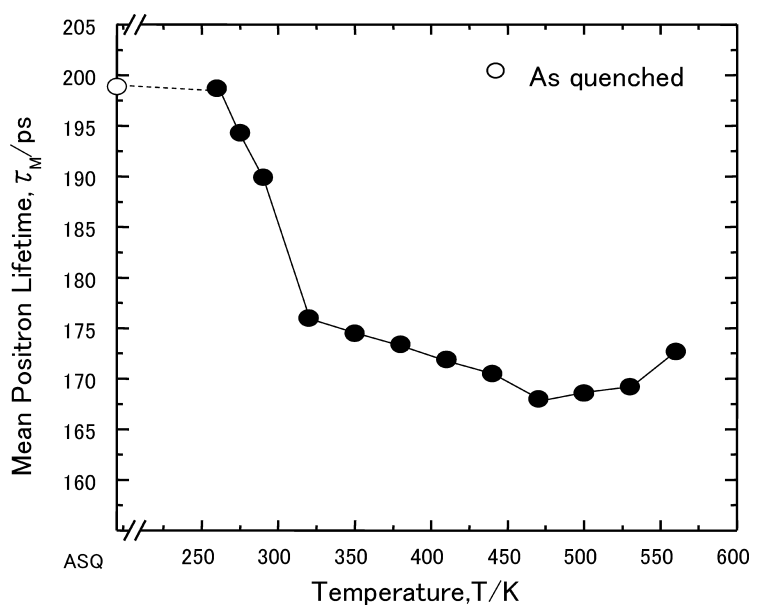

図 6 高純度アルミニウム中の凍結空孔とその挙動 ${ }^{8)}$ 。 横軸は等時焼なまし温度。空孔は室温以下で移動し, 一部は二次欠陥（転位ループ）になる。

濃度が異なる試料について，同一の急冷条件を与えることは， 凍結空孔の挙動を比較研究する上で, 極めて重要である。

図 6 に, 純アルミニウム中の凍結空孔の，等時焼なましに 伴う回復挙動 8)を示す。 $5 \mathrm{~N}$ (99.999\%) の純アルミニウムを 図 5 の急冷炉を用いて，678K から $253 \mathrm{~K}$ の食塩水中に焼入

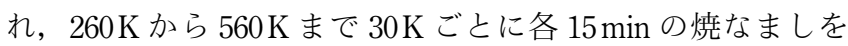
施し, 陽電子寿命を測定した。陽電子寿命の測定温度は $110 \mathrm{~K}$ であり, 測定中の試料内部の変化は無視できる。横軸 は焼なまし温度, 縦軸は平均陽電子寿命である。急冷直後の 陽電子寿命は約 200 ps であり, 熱平衡空孔が凍結されている ことがわかる。室温以下に見られる平均陽電子寿命の減少 は，凍結空孔がこのような低温でも，移動・消滅することを 明瞭に示している。純アルミニゥム中の空孔は室温以下で移 動・消滅し，一部は 2 次欠陥として転位ループを形成するこ 之が知られている ${ }^{1,6,6) 9}$ 。転位ループになると比較的安定にな るが，図6でも見られるように，転位ループも $400 \mathrm{~K}$ から $500 \mathrm{~K}$ 付近で分解消滅する ${ }^{1), 9}$ 。 $500 \mathrm{~K}$ 以上で陽電子寿命が再 び上昇するのは，等時焼なまし温度における熱平衡原子空孔 が再び試料中に凍結されるためである（等時焼なまし後その 温度加急冷している)。

\section{6. アルミニゥム中の空孔挙動に与える溶質原子の効 果 $(\mathrm{Sn}$ の例)}

溶質原子は，原子空孔の移動に極めて大きな影響を与え る。ここでは，アルミニウム合金の時効現象に大きな効果を 持つ, Sn の例を示す。図 7 は, 希薄 Al-Sn 合金中の凍結空 孔の，等時焼なましに伴う回復挙動を示す 8 。 試料として, 図 6 の実験に用いたものと同じ $5 \mathrm{~N}$ の純アルミニウムに $5 \mathrm{~N}$ の 純すずを添加し，Al-0.018at\%Sn 合金を作成した。純アルミ ニウムの場合と同様に図 5 に示した急冷炉を用い, $778 \mathrm{~K}$ か ら水水中に急冷した。急冷温度を上げたのは，Sn の固溶限 を確実にクリアし，固溶を保障するためである。等時焼なま し条件ならびに陽電子寿命の測定条件は, 前項の純アルミニ ウムの場合と同じである。

純アルミニウムの場合（図 6) と, Sn 添加材の場合（図 7) を比較して, まず目に付くのは, 急冷直後の值が Sn 添加材 の場合, 約 $230 \mathrm{ps}$ 之高い点である。この原因は, 単に急冷温

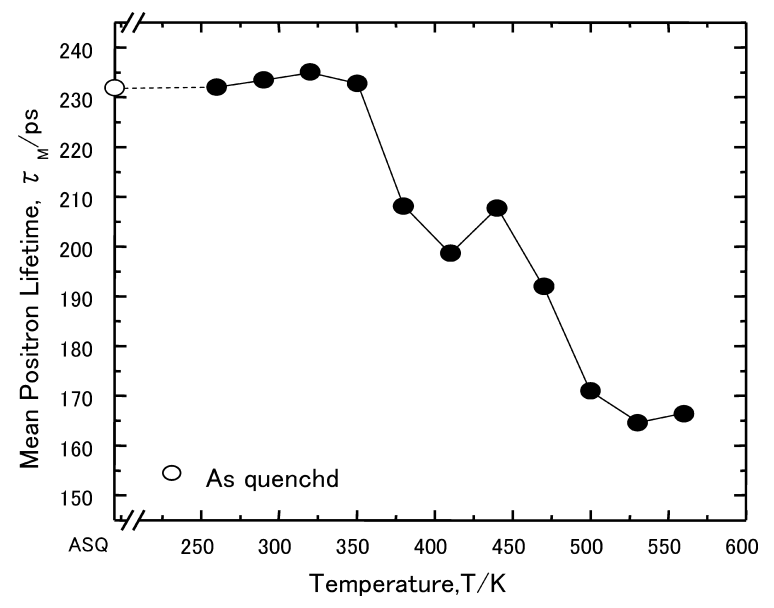

図 $7 \mathrm{Sn}$ を $0.018 \mathrm{at} \%$ 添加したアルミニウム中の原子空 孔挙動 ${ }^{8)}$ 。空孔の移動温度が純アルミニウムの場合 （図 6 参照）に比べて大きく高温側にシフトしている。

度が高いせいではなく, 固溶している $\mathrm{Sn}$ 原子と原子空孔の 強い相互作用の結果, 多量の原子空孔が凍結されたせいであ る。溶体化温度でアルミニゥム中に形成された熱平衡原子空 孔は, 急冷中に温度低下に従って sinks に消えようと拡散す るが，その途中で固溶 Sn 原子と結合し，足止めされる。そ のため, 純アルミニウムの場合と比較すると, はるかに多量 の原子空孔が材料中に凍結されている。また, ほとんどの凍 結空孔が単一空孔 - 溶質複合体の形で試料中に凍結されてい るため，陽電子寿命值はほぼ $230 \mathrm{ps}$ に飽和している。

アルミニゥム中の原子空孔と固溶 Sn 原子との強い相互作 用は, その後の回復挙動に更に明確に現れている。まず, 図 7 から明らかなように凍結空孔は $\mathrm{Sn}$ 原子に捕獲され $350 \mathrm{~K}$ 付

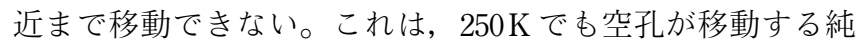
アルミニウムの場合（図6参照）と大きく異なる。アルミニ ウムに Sn が添加された場合, 室温時効が抑制される現象は 知られていたが，この測定結果は，その原因は Sn 原子が原 子空孔を捕獲しその移動を強く抑制するためであることを， 疑いの余地なく示している。詳細は研究論文 ${ }^{8)}$ に譫るが，そ の後も原子空孔之 $\mathrm{Sn}$ 原子は相互作用を持ち, $400 \mathrm{~K}$ 付近で一 度平均寿命が上昇したあと, $450 \mathrm{~K}$ を越えてからようやく大 量の過剩空孔が移動・消滅に向汃う (図 7 参照)。低温時効 では時効を遅らせる $\mathrm{Sn}$ 原子が, 高温時効では析出を促進す ると期待されるが，その理由はここにある。

わずか 180 at ppm の溶質を添加しただけで，原子空孔の移 動温度が 200 度も上昇する理由は, 原子空孔と $\mathrm{Sn}$ 原子との 直接相互作用以外にあり得ない。析出による影響など他の解 釈の可能性をなくするために, あえて $0.018 \mathrm{at} \% \mathrm{Sn}$ という超希 薄合金を作成し, 測定対象とした。本実験条件では凍結空孔 の量は数十 ppm のオーダであり, 180 atppm の Sn 原子から 充分に劇的な影響を受ける。他の溶質原子と原子空孔之の相 互作用については別の機会に譲る。

\section{7. 空孔挙動に与える析出の影響（Al-Cu 合金の例）}

析出物がある場合の空孔挙動を見るために, 最む基本的な アルミニウム - 銅二元合金の例 ${ }^{10)}$ を図 8 に示す。Al$4 \mathrm{mass} \% \mathrm{Cu}$ 合金を $803 \mathrm{~K}$ で溶体化処理した後, 直ちに氷水中 に焼入れた。ただし，この場合は図 5 の急冷専用炉を用いて 


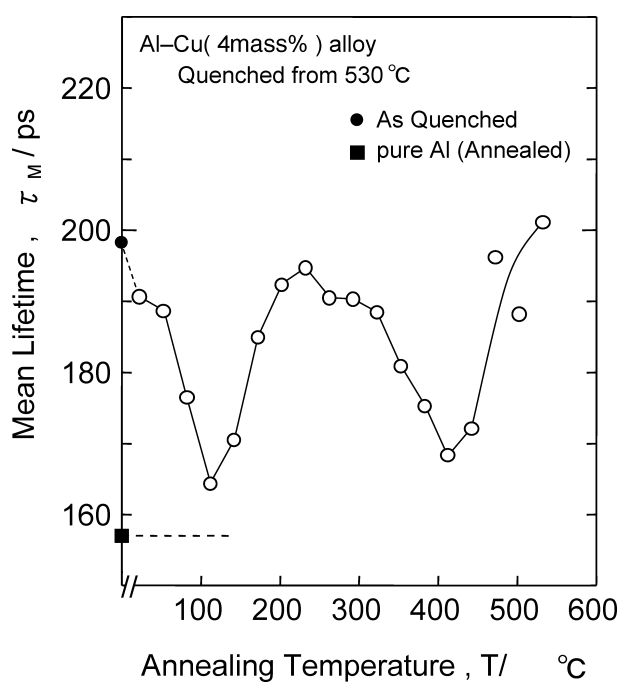

図 $8 \mathrm{Al}-4 \mathrm{mass} \% \mathrm{Cu}$ 合金中の空孔挙動 ${ }^{10)}$ 。空孔移動温 度の高温側へのシフト以外に, 析出物形成に伴い空孔 が導入されることが示唆されている。

いないため, 急冷速度は純アルミニウム（図 6）や希薄 Al-Sn 合金の場合（図 7）よりも遅い。それで屯，急冷直後の值は 完全結晶の陽電子寿命より約 $40 \mathrm{ps}$ 高く, 過剰空孔が材料中 に凍結されていることがわかる。

その後の等時焼なまし（この場合は $30 \mathrm{~K}$ ごとに各 200 分焼 なまし）過程の变化（図 8）に目を移すと，アルファベット の W の形をしていることが特徴である。まず，室温から $380 \mathrm{~K}$ 付近にかけての平均陽電子寿命の下がりは, 凍結空孔 が移動し, sinks に消滅する過程を見ている。この空孔移動 の温度は, 室温以下で空孔が移動する純アルミニウムの場合 （図 6）に比べて $100^{\circ} \mathrm{C}$ 程度高い。しかし, 希薄 $\mathrm{Al}-\mathrm{Sn}$ 合金の 場合（図 7）に比べると, $100^{\circ} \mathrm{C}$ 以上低い。つまり, アルミ ニウム中の銅原子あ空孔と結合エネルギーを有し，空孔の移 動温度を高温側にシフトさせるが, その程度は, Sn 原子の場 合ほど大きくはないことを示している。

$673 \mathrm{~K}$ 以上に見られる平均陽電子寿命の上昇は，各焼なま し温度における熱平衡空孔が，再び材料中に凍結されている せいである。図 8 の変化で, 純アルミニウム（図 6）や希薄 $\mathrm{Al}-\mathrm{Sn}$ 合金の場合（図 7) と最む異なる特徵は，400～ $500 \mathrm{~K}$ に 見られる平均陽電子寿命の異常な上昇である。これが, 銅原 子の析出に伴う変化であることは, 疑いの余地はない。何が 起こっているかを明らかにするために，陽電子消滅スペクト ルの成分解析を行い, 形成されている欠陥の種類を調べると, 急冷直後と同じ種類の欠陥すなわち単原子空孔が形成されて いることが明らかとなった ${ }^{10)}$ 。

この点をより明確にするために，同じ $\mathrm{Al}-4 \operatorname{mass} \% \mathrm{Cu}$ 合金 を $803 \mathrm{~K}$ から焼入れ，403K で等温焼なましを行った結果 ${ }^{10)}$ を図 9 に示す。横軸は焼なまし時間, 縦軸は平均陽電子寿命 を示す。急冷操作によって凍結された空孔は，0.25 時間以内 に急激に減少するが，それ以降平均寿命は上昇に転じ， 128 時間で急冷直後よりあ高い $216 \mathrm{ps}$ まで上昇する。成分解析を 行うと, この平均寿命の上昇は, 空孔屯しくはそのクラス夕 が形成されていることが示唆される ${ }^{10)}$ 。一方, 従来の研究に よれば，図 9 で平均陽電子寿命の上昇が観察されている時間 域は，まさに GPIゾーンが形成される時効条件である。この

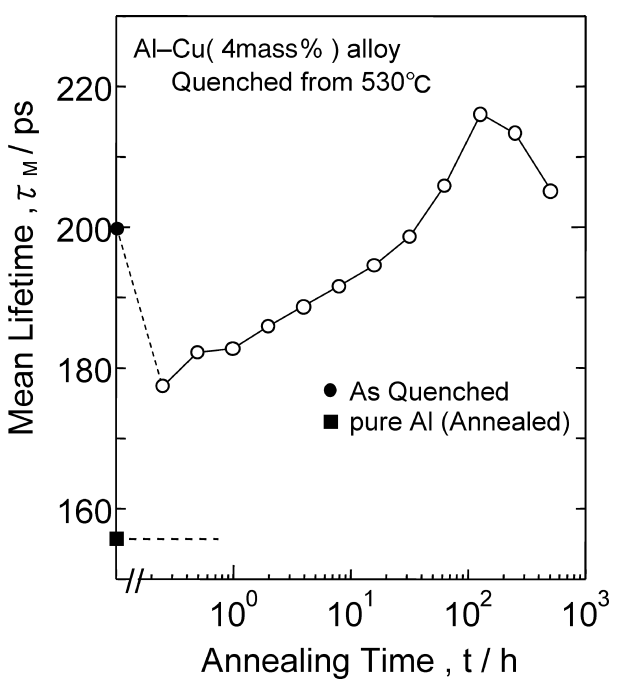

図 $9403 \mathrm{~K}$ で等温焼なましされた $\mathrm{Al}-4 \mathrm{mass} \% \mathrm{Cu}$ 合金中 の空孔挙動 ${ }^{10)}$ 。GPI ゾーン形成に伴い空孔が導入され ることが示唆されている。

観察結果から, われわれは GPI ゾーンの形成に伴って, 新た に (凍結空孔とは別に) 原子空孔が形成されると考えている。 従来の教科書には記述のない新しい空孔形成機構であるが, 我々は類似の異常空孔形成現象を, 他の相变態 (規則・不規

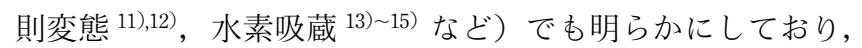
「相変態誘起空孔」と名付けている。詳細はここでは述べな いが, 内部ひずみが主要原因である ${ }^{16)}$ 。 $\mathrm{Al}-\mathrm{Cu}$ 合金の場合 は, GPI ゾーンが持つ大きな内部ひずみが, 空孔濃度を増大 させていると考えられる。

最近は，いくつかの 6000 系のモデル合金についても，本稿 で述べたような測定を行い, 空孔や析出物の挙動を調べてい るが, その成果については, 紙面の関係で別の機会に譲りた い。

\section{8.おわりに}

1970 年前後に, 陽電子は物質中の原子空孔型欠陥に捕獲さ れ，その位置で電子と対消滅することが正しく認識された。 空孔型欠陥中では電子密度が低いため陽電子寿命は長くな り，それぞれの欠陥種に固有の值（150ps $500 \mathrm{ps）をとる。}$ 検出感度は, 原子空孔の場合通常 $1 \mathrm{ppm}$ 程度でも測定に掛か り，100 ppm あればほぼすべての陽電子は原子空孔に捕獲さ れて消滅する。つまり, 陽電子は微弱な欠陥の信号をおよそ $10^{4}$ 倍に増幅してくれる訳で, この手法の持つ優れた特徽と なっている。

陽電子寿命法は元来非破壊で, 高感度にその場測定が可能 であり, しかも各欠陥種とその濃度を独立に求めることがで きる。この特徵は, 陽電子が物質を構成する電子の反粒子で あり, 正の電荷を持つという点から生じており, 原子空孔研 究に関して, 今後屯独自の有用性を発揮してゆく之期待され る。さらに, 陽電子消滅 $\gamma$ 線同時計数ドップラー広がり法の 出現により, 空孔周辺の元素分布や, 溶質ナノクラスタその むのの研究も可能となりつつある。今後アルミニウム合金に ついてあより詳細な研究が可能になると期待される。 


\section{参 考 文 献}

1）白井泰治：日本金属学会会報，27（1988）， 869-877.

2) Y. Shirai, K. Matsumoto, G. Kawaguchi and M. Yamaguchi: Mater. Sci. Forum, 105-110 (1992), 1225-1228.

3) M. Mizuno and Y. Shirai: unpublished.

4) M. J. Puska and R. M. Nieminen: J. Phys. F, 13 (1983), 333

5）白井泰治：まてりあ, 39 (1998), 567-570.

6）白井泰治：まてりあ， 37 (2000)，61-67.

7) W. Eckert and H.-E. Schaefer: in Positron Annihilation 8, (eds. L. Dorikens-Vanpraet, M. Dorikens and D. Segers), World Scientific, Singapore, (1989), p. 407.

8）木原照夫, 荒木秀樹, 水野正隆, 白井泰治：未出版.
9）白井泰治，山口正治：バウンダリー， 5（1989），22-27.

10）見角幸一，荒木秀樹，水野正隆，白井泰治：未出版.

11） Y. Shirai, F. Nakamura, M. Takeuchi, K. Watanabe and M. Yamaguchi: in Positron Annihilation 8, (eds. L. Dorikens-Vanpraet, M.Dorikens and D.Segers), World Scientific, Singapore, (1989), p. 488.

12) P. Chalermkarnnon, H. Araki and Y. Shirai: Materials Transactions JIM, 43 (2002), 1486-1488.

13) Y. Shirai, H. Araki, T. Mori, W. Nakamura and K. Sakaki: J. Alloys and Compounds, 330-332 (2002), 125-131.

14) K. Sakaki, T. Yamada, M. Mizuno, H. Araki and Y. Shirai: Materials Transactions JIM, 43 (2002), 1486-1488.

15）白井泰治，荒木秀樹，榊 浩司：金属，72（2002），660-663.

16) Y. Shirai et al.: to be published. 